University of Massachusetts Amherst

From the SelectedWorks of Bruce Byers

2004

Extrapair Paternity Increases Variability IN Male Reproductive Success in the Chestnut-Sided Warbler (Dendroica Pensylvanica), A Socially Monogamous Songbirds

Bruce Byers, University of Massachusetts - Amherst 


\title{
EXTRAPAIR PATERNITY INCREASES VARIABILITY IN MALE REPRODUCTIVE SUCCESS IN THE CHESTNUT-SIDED WARBLER (DENDROICA PENSYLVANICA), A SOCIALLY MONOGAMOUS SONGBIRD
}

\author{
Author(s) :Bruce E. Byers, Herman L. Mays Jr., Ian R. K. Stewart, and David F. Westneat \\ Source: The Auk, 121(3):788-795. 2004. \\ Published By: The American Ornithologists' Union \\ DOI: http://dx.doi.org/10.1642/0004-8038(2004)121[0788:EPIVIM]2.0.CO;2 \\ URL: http://www.bioone.org/doi/full/10.1642/0004-8038\%282004\%29121\%5B0788\%3AEPIVIM \\ $\% 5 \mathrm{D} 2.0 . \mathrm{CO} \% 3 \mathrm{~B} 2$
}

BioOne (www.bioone.org) is a nonprofit, online aggregation of core research in the biological, ecological, and environmental sciences. BioOne provides a sustainable online platform for over 170 journals and books published by nonprofit societies, associations, museums, institutions, and presses.

Your use of this PDF, the BioOne Web site, and all posted and associated content indicates your acceptance of BioOne's Terms of Use, available at www.bioone.org/page/terms_of use.

Usage of BioOne content is strictly limited to personal, educational, and non-commercial use. Commercial inquiries or rights and permissions requests should be directed to the individual publisher as copyright holder. 


\title{
EXTRAPAIR PATERNITY INCREASES VARIABILITY IN MALE REPRODUCTIVE SUCCESS IN THE CHESTNUT-SIDED WARBLER (DENDROICA PENSYLVANICA), A SOCIALLY MONOGAMOUS SONGBIRD
}

\author{
Bruce E. Byers, ${ }^{1,3}$ Herman L. Mays, Jr., ${ }^{2,4}$ IAn R. K. Stewart, ${ }^{2}$ \\ and David F. Westneat ${ }^{2}$ \\ ${ }^{1}$ Department of Biology, University of Massachusetts, Amherst, Massachusetts 01003, USA; and \\ ${ }^{2}$ Center for Ecology, Evolution, and Behavior and Department of Biology, University of Kentucky, Lexington, \\ Kentucky 40506, USA
}

\begin{abstract}
Aвstract.-A monogamous mating system that includes extrapair fertilization can potentially generate higher variability in male reproductive success than monogamy without extrapair fertilization. That increased variability could provide a correspondingly higher opportunity for sexual selection and, thus, for the origin and persistence of sexual dimorphism in monogamous species. To determine whether extrapair fertilization enhanced the opportunity for sexual selection in a sexually dimorphic, monogamous bird species, we used microsatellite DNA typing to assess the prevalence of extrapair fertilization and its effect on variation in male reproductive success in a population of Chestnut-sided Warblers (Dendroica pensylvanica). We found that the level of extrapair fertilization in our study population was at the upper end of the range reported for bird populations ( $47 \%$ of nestlings had extrapair fathers; $61 \%$ of broods contained extrapair offspring). We also discovered that almost all extrapair offspring were sired by paired males resident on nearby territories. In addition, we found that variation in male reproductive success was substantially higher than variation in female reproductive success, and that extrapair fertilizations made a significant contribution to variation in male reproductive success. Together, those findings suggest that extrapair fertilization creates an opportunity for sexual selection on male traits in this population. Received 24 May 2003, accepted 28 March 2004.
\end{abstract}

Resumen.-Un sistema de apareamiento monógamo que incluye fertilización extra-pareja puede potencialmente generar mayor variabilidad en el éxito reproductivo de los machos que la monogamia sin fertilización extra-pareja. Este incremento en la variabilidad podría a su vez significar una mayor oportunidad para selección sexual y, por lo tanto, para el origen y la persistencia de dimorfismo sexual en las especies monógamas. Para determinar si la fertilización extra-pareja aumenta la oportunidad para selección sexual en una especie de ave monógama sexualmente dimórfica, usamos ADN microsatelital para determinar los genotipos y evaluar la predominancia de la fertilización extra-pareja y sus efectos en la variación en el éxito reproductivo de los machos en un población de Dendroica pensylvanica. Encontramos que el nivel de fertilización extra-pareja en nuestra población de estudio se ubicó en el extremo superior del rango registrado para poblaciones de aves (47\% de los pichones presentaron padres extra-pareja; $61 \%$ de las nidadas presentaron pichones extra-pareja). También descubrimos que casi todos los pichones extra-pareja fueron engendrados por machos en pareja y residentes en territorios vecinos. Además, encontramos que la variación en el éxito reproductivo de los machos fue substancialmente mayor que la variación en el éxito reproductivo de las hembras, y que las fertilizaciones extra-pareja tuvieron una contribución significativa a la variación en el éxito reproductivo de los machos. En conjunto, estos hallazgos sugieren que la fertilización extra-pareja crea una oportunidad para la selección sexual de los caracteres de los machos en esta población.

${ }^{3}$ E-mail: bbyers@bio.umass.edu

${ }^{4}$ Present address: Department of Biological Sciences, Auburn University, Auburn, Alabama 36849, USA 
Both MonogAmy AND sexual dimorphism are widespread among bird species (Lack 1968, Owens and Hartley 1998), but evolutionary biologists have historically found it difficult to reconcile their coexistence within species (Gowaty and Mock 1985). How can a monogamous mating system, which seems to limit the potential for large differences in reproductive success among males, provide the strong sexual selection that is presumably required for evolution of bright plumage and elaborate vocalizations in males? A potential solution to this apparent paradox arises from the finding that, in a wide variety of nominally monogamous bird species, many nests contain offspring that were not fathered by the mother's social mate (Westneat et al. 1990, Petrie and Kempenaers 1998, Griffith et al. 2002). Such extrapair fertilization (EPF) could increase variability in male reproductive success beyond that attributable to variation in female fecundity (Møller and Birkhead 1994, Møller and Ninni 1998).

Although EPFs clearly have the potential to generate variability in male reproductive success, a high-level of extrapair paternity will not necessarily increase variation in success. If, for example, there is a trade-off between activities required to achieve EPFs and those required to defend against cuckoldry (Arak 1984, Alatalo et al. 1986, Westneat et al. 1990), paternity gained by EPFs may be offset by paternity lost at the home nest, and net reproductive success of males that are successful at gaining EPFs may not differ from that of males that do not gain EPFs. Therefore, accurate assessment of variability in male reproductive success must account for both extrapair and within-pair fertilizations. Measuring both of those components of reproductive success also allows one to estimate the relative contribution of each component to overall variance in success.

Here, we assessed the potential for sexual selection, as estimated by variance in male reproductive success (Arnold and Wade 1984), in the Chestnut-sided Warbler (Dendroica pensylvanica), a socially monogamous, migratory songbird. The plumage of male Chestnut-sided Warblers is much brighter and more conspicuous than that of females, and males (but not females) sing elaborate songs and exhibit complex singing behavior (Byers 1995). Males defend nesting territories during the breeding season, but both males and females make regular forays onto neighboring territories (B. E. Byers pers. obs.), which suggests that EPFs may occur. The species is thus a suitable subject for exploring the relationship between EPFs, male reproductive success, and potential for sexual selection.

\section{Methods}

\section{Study Site and Field Methods}

We studied a population of Chestnut-sided Warblers nesting within a powerline corridor in Savoy State Forest in Berkshire County, Massachusetts $\left(42^{\circ} 40^{\prime} \mathrm{N}, 73^{\circ} 3^{\prime} \mathrm{W}\right)$. The corridor supports the shrubby habitat preferred by breeding Chestnut-sided Warblers and is surrounded by dense deciduous forest in which the warblers do not generally nest. Thus, the powerline corridor provided a linear array of Chestnut-sided Warbler breeding territories. The study area contained 19 territories in 1999, 2 of which were occupied by unpaired males; and 20 territories in 2000, all of which held breeding pairs. Five birds (three males and two females) were present in both 1999 and 2000; none of those returning birds had the same social mate in both years.

We captured adult birds in May of 1999 and 2000 by using song playback to lure them to mist nests. A few birds that evaded early capture were caught later in the breeding season by passive netting. We marked each bird with an individually distinctive combination of colored leg bands and took a small blood sample $(\sim 50 \mu \mathrm{L})$ from the brachial vein. We obtained blood samples from all territorial adults in the study area, as well as from all other adults captured there. Overall, we obtained blood samples from 61 males $(29$ in 1999 and 32 in 2000) and from 49 females (24 in 1999 and 25 in 2000). The linear configuration of territories, bounded by habitat unsuitable for breeding, ensured that we sampled the territorial neighbors of all pairs, except those on the territories at each end of the study area (each of those two pairs had one neighboring pair that was outside of the study area).

We banded and obtained blood samples from nestlings on the fifth or sixth day after hatching, the most advanced age at which the young birds could be handled without risk of premature fledging. Brood sizes ranged from one to four nestlings. At least one bird from each sampled nest was later observed on its natal territory, which suggests that all or most of the sampled nestlings fledged successfully. Overall, we sampled a total of 95 nestlings (45 in 1999 and 50 in 2000) from 33 nests (15 in 1999, 18 in 2000). That sample represented all the nests in the study area that fledged young. Because Chestnut-sided Warblers in the population rear only one brood per year (B. E. Byers pers. obs.), each nest sampled in a year belonged to a different pair. 


\section{Parentage Analysis}

We determined parentage of nestlings by comparing nestling and adult genotypes at four microsatellite loci. We isolated DNA from blood samples by phenolchloroform extraction (modified from Quinn and White 1987); microsatellite loci were amplified by polymerase chain reaction (PCR). For the 1999 samples, primers were end-labeled with ${ }^{32} \mathrm{P}$ prior to amplification. The PCR products were electrophorectically sorted by size on $4 \%$ denaturing polyacrylamide gels and visualized by exposing dried gels to autoradiography film for 12-24 h (for the radioactively labeled products) or by silver staining (Bassam et al. 1991).

The 1999 samples were typed at two loci (Dp $\mu 1$ and Dp 16 ) originally isolated from Yellow Warblers (D. petechia; Dawson et al. 1997) and at two loci (Lsw 14 and Lsw 18 18) isolated from Swainson's Warblers (Limnothlypis swainsonii; Winker et al. 1999). For unknown reasons, however, the Lsw $\mu 18$ locus did not consistently yield readable gels with the silverstaining method that we used with the 2000 samples, so we instead used the Yellow Warbler locus DP $\mu 05$ as the fourth locus for those samples.

On the gels, samples from members of social families were grouped together in adjacent lanes to facilitate within-gel comparisons. We ensured consistent scoring of fragment sizes across gels by running reference standards in three or four lanes on each gel. The references consisted of either a ladder of alleles drawn from selected adults (1999 samples) or a commercially prepared 10-base-pair ladder (Gibco BRL, Invitrogen Life Technologies, Gaithersburg, Maryland; 2000 samples).

Because each nestling (with one exception discussed below) shared an allele at each locus with its social mother, we concluded that the social mother of each nestling was also its biological mother, and thus that intraspecific brood parasitism was rare or absent. We therefore assessed paternity by comparing each nestling's nonmaternal allele at each locus first to those of its social father and, if there were mismatches, to alleles of the other males in the population. A nestling was judged to have been sired by its social father if it shared the paternal allele with the social father at all four loci (two exceptions to this criterion are discussed below). Nestlings with paternal mismatches were judged to be extrapair offspring. When comparing genotypes of those extrapair offspring with those of other males in the population, we deemed only males that matched the nestling at all four loci to be candidates for true paternity. We reran samples from these candidate fathers alongside samples from their putative offspring to confirm allele matches.

\section{Paternity Statistics}

We used CERVUS 2.0 (Marshall et al. 1998) to calculate expected frequencies of heterozygotes and null alleles at each locus. Given the observed frequency of each allele and assuming that all loci were at Hardy-Weinberg equilibrium, CERVUS calculated the expected frequency of heterozygotes $\left(H_{e}\right)$ at each of the five loci. A large difference between $H_{e}$ and observed frequency $\left(H_{o}\right)$ suggests that a null allele (one that does not amplify) is present in the sampled population. The expected frequency of such null alleles can be estimated from $H_{e}$ and $H_{o}$ (Summers and Amos 1997).

We also used CERVUS to calculate average exclusion probability at each locus. This value represents the probability that the alleles of an unrelated adult male chosen at random will mismatch a nestling's paternal allele (i.e. be excluded), given that the maternal allele is known. After determining exclusion probabilities at each locus, we combined probabilities across all loci to determine the average probability that a randomly chosen unrelated male will be excluded from paternity at one or more loci.

\section{Male Reproductive Success}

We measured each male's reproductive success as the sum of his biological offspring in his own nest and number of his offspring detected in the nests of other males. The reproductive success of individuals that were present in both years of the study was calculated as the per-year average. To assess the potential for sexual selection among males, we calculated the standardized variance (variance divided by mean-squared) of reproductive success, and used the method described by Webster et al. (1995) to partition the variance into three components, corresponding to the contribution made by (1) offspring fathered with social mate, (2) offspring fathered with other females, and (3) covariance between within-pair and extrapair reproduction. We further partitioned within-pair variance to distinguish between the portion attributable to variability in fecundity (brood size) of social mates and the portion attributable to variability in level of cuckoldry at the home nest.

To determine if all males were equally susceptible to cuckoldry, we compared the distribution of extrapair young among nests with the distribution expected if extrapair young were distributed at random. In this comparison, the null (random) distribution was taken to be a multivariate hypergeometric distribution (Neuhauser et al. 2001); expected values were calculated using the SticiGui Probability Calculator (see Acknowledgments).

\section{RESUlts}

The microsatellite loci used in the paternity analysis provided high power to detect extrapair paternity (Table 1), yielding combined exclusion probabilities of 0.998 for the 1999 sample and 
TABLE 1. Heterozygosity, null allele frequency, and power of exclusion of microsatellite loci used in Chestnut-sided Warbler paternity analysis.

\begin{tabular}{|c|c|c|c|c|c|}
\hline Locus & $\begin{array}{l}\text { Number of } \\
\text { alleles }\end{array}$ & $\begin{array}{c}\text { Observed } \\
\text { heterozygosity }\end{array}$ & $\begin{array}{c}\text { Expected } \\
\text { heterozygosity }\end{array}$ & $\begin{array}{c}\text { Estimated } \\
\text { frequency of } \\
\text { null alleles }\end{array}$ & $\begin{array}{c}\text { Probability } \\
\text { of } \\
\text { exclusion }^{\mathrm{a}}\end{array}$ \\
\hline \multicolumn{6}{|c|}{1999} \\
\hline Dp $\mu 01$ & 24 & 0.939 & 0.939 & 0.002 & 0.866 \\
\hline Dp $\mu 16$ & 11 & 0.827 & 0.844 & 0.005 & 0.686 \\
\hline Lsw $\mu 14$ & 7 & 0.667 & 0.769 & 0.071 & 0.550 \\
\hline Lsw 418 & 31 & 0.828 & 0.947 & 0.062 & 0.881 \\
\hline Combined & & & & & 0.9978 \\
\hline \multicolumn{6}{|c|}{2000} \\
\hline Dp $\mu 01$ & 24 & 0.837 & 0.944 & 0.058 & 0.877 \\
\hline Dp 416 & 14 & 0.591 & 0.799 & 0.155 & 0.625 \\
\hline Lsw $\mu 14$ & 8 & 0.527 & 0.764 & 0.193 & 0.552 \\
\hline Dp $\mu 05$ & 14 & 0.804 & 0.811 & 0.002 & 0.631 \\
\hline Combined & & & & & 0.9925 \\
\hline
\end{tabular}

0.993 for the 2000 sample. The predicted frequency of null alleles was negligible for the 1999 sample but was comparatively high at two loci in

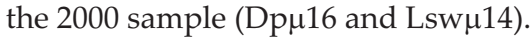

\section{Effects of Null Alleles on Paternity Assessment}

We took the relatively high likelihood of null alleles at those loci into consideration when evaluating parentage. In particular, three nestlings in one brood were scored as homozygous at locus Dp $\mu 16$ with an allele that matched one of the social father's alleles, and thus those nestlings appeared to have no allele contributed by their social mother, who was scored as homozygous for a nonmatching allele. If, however, the offspring had inherited a null, nonamplifying allele from their social mother, their genotype at that locus would be consistent with a match to the two social parents. Because the offspring matched their social parents at the other three loci, and because no other nestlings in the study population mismatched their social mothers, we concluded that the most likely scenario was that the nestlings had indeed inherited a maternal null allele, and we classified those three nestlings as within-pair offspring.

In one other case, a single nestling was apparently homozygous at locus Lsw $\mu 14$, with an allele that matched one of its mother's alleles, whereas its social father was apparently homozygous for a different allele. Again, the nestling matched both parents at the other three loci, and we reasoned that the most parsimonious explanation was transmission of a paternal null allele. We therefore classified that nestling as a within-pair offspring.

Although microsatellite loci are not thought to exhibit extraordinarily high rates of mutation (Primmer et al. 1998, Hancock 1999), we encountered two offspring mismatches that in our judgment were best explained by mutations in parental gametes. Two offspring, from two different nests, matched their social fathers at three of the four loci, but mismatched at the fourth locus (one offspring at Dp $\mu 16$, the other at Lsw 114 ). We deemed it unlikely that those offspring had extrapair fathers, because the probability that an unrelated male would by chance match a nestling at three loci was low ( 0.02), and the chances of that unlikely event occurring twice in our study population was even lower. We therefore concluded that the social fathers of those two nestlings were probably the biological fathers, and the single mismatched locus in each case was attributable to either a scoring error or a mutation. To test for scoring errors, we reran samples from the two offspring on gels alongside samples from their social fathers, and this repetition of the original analysis confirmed the pattern of a single mismatch for each offspring. We therefore concluded that the single mismatches were due to mutations and classified the two nestlings as within-pair offspring. 


\section{Extrapair Paternity}

The level of extrapair paternity in the study population was high in both years. Overall, 20 of 33 nests $(60.6 \%)$ contained one or more extrapair young; three of those nests contained offspring of two different extrapair fathers. Forty-five of 95 nestlings (47.4\%) had extrapair fathers. Proportion of nests containing extrapair offspring did not differ between the two years of the study $\left(\chi^{2}=0.60, \mathrm{df}=1, P=0.44\right)$, nor did the proportion of extrapair offspring $\left(\chi^{2}=0.90\right.$, $\mathrm{df}=1, P=0.34)$. Extrapair fertilizations were distributed nonrandomly among nests (broods of two: $\chi^{2}=10.7, \mathrm{df}=2, P=0.04$; broods of three: $\chi^{2}$ $=11.8, \mathrm{df}=3, P=0.008$; broods of four: $\chi^{2}=14.9$, $\mathrm{df}=4, P=0.005)$. For all brood sizes, number of nests with zero and with many extrapair young exceeded random expectation.

\section{IDENTITY OF EXTRAPAIR FATHERS}

We were able to identify the genetic fathers of 39 of the 45 extrapair offspring. With one exception, each of these extrapair offspring was matched at all four loci by only a single male. One extrapair offspring was matched at all four loci by two males. One of these males was resident three territories away from the nestling; the other was a bird that we captured very early in the breeding season, but that subsequently disappeared from the study area. We therefore assigned paternity to the locally territorial male.

Eighteen different males sired the extrapair offspring for which we identified fathers. Among the extrapair fathers, $10(56 \%)$ had nests that contained offspring sired by other males, and $2(11 \%)$ failed to fledge any offspring with their social mates, as their nesting attempts failed due to predation. Neither of these proportions differed significantly from the corresponding proportions in the study population as a whole (Fisher's exact test; $P=0.71$ and 0.76 , respectively).

With one exception, all extrapair fathers were paired when their extrapair partners laid eggs, and most of the extrapair fathers seem to have secured their EPFs around the time their social mates began laying eggs. In $77 \%$ of the EPFs for which paternity was assigned, the first egg in the nest containing a male's extrapair offspring was laid within four days before $(54 \%)$ or after $(23 \%)$ the first egg was laid in the male's own nest. The remaining EPFs were secured either later in the incubation period of a male's social mate $(15 \%)$ or after the young on a male's home territory had fledged $(8 \%)$. Those later EPFs were possible because, although most pairs initiate nests within a narrow time window in late May, pairs that lose nests to predation may renest later in the season. None of the assigned EPFs was achieved by a male who was feeding nestlings.

Most of the extrapair offspring were fathered by a male resident on a nearby territory $(28 \%$ by a male on a neighboring territory, $62 \%$ by a male two or three territories distant). A few offspring, however, were sired by more distant males from as far as 10 territories away. Territories are fairly small in this population (mean width $=\sim 45 \mathrm{~m}$ ), so even the most-distant known extrapair father in the study area resided $\leq 400 \mathrm{~m}$ from his offspring's nest. In addition, single nestlings from two different nearby nests were fathered by a male that was captured in the vicinity of the nests but was not resident in the study area. That male may have been a territorial male from outside the study area, or he may have been a nonterritorial floater.

\section{Variance in Reproductive Success}

Variance in male reproductive success was far higher than variance in female reproductive success (Table 2). Variance in within-pair and extrapair reproductive success contributed in roughly equal measure to overall variance in male reproductive success. About a third of variance in within-pair success was attributable to loss of paternity within the home nest. The covariance term of the partitioned variance was negligible, which indicates that a male's success at ensuring paternity within his own nest was not closely tied to his success at obtaining EPFs. That is, there appears to have been no trade-off between the two components of reproductive success (as would be indicated by a large, negative covariance), nor were males who succeeded at one component especially likely to have succeeded at the other component (as would be indicated by a large, positive covariance).

\section{Discussion}

Extrapair Fertilizations and Opportunity For Sexual Selection

Extrapair fertilization clearly plays a significant role in the mating system of Chestnut-sided 
TABLE 2. Reproductive success of male and female Chestnut-sided Warblers in 1999 and 2000, showing that variance in male success exceeded variance in female success and that EPFs made an important contribution to overall variance in male success.

\begin{tabular}{lccccc}
\hline \hline & & & & & \multicolumn{2}{c}{$\begin{array}{c}\text { Standardized } \\
\text { variance }\end{array}$} \\
\hline Female reproductive success & 35 & $0-4$ & 2.73 & 1.39 & 0.187 \\
Male reproductive success & 37 & $0-7$ & 2.31 & 3.75 & 0.701 \\
$\quad$ Within pair & & $0-4$ & 1.43 & 2.09 & 0.391 \\
$\quad$ due to female fecundity & & & & 1.22 & 0.228 \\
$\quad$ due to cuckoldry & & & 0.71 & 0.133 \\
$\quad$ Extrapair & $0-6$ & 0.88 & 1.66 & 0.310 \\
Covariance & & & & 0.015 \\
\hline
\end{tabular}

Warblers. Almost half of the nestlings produced in the study population were sired by extrapair fathers, a level at the upper end of the range reported for bird species (see figure 1 in Griffith et al. 2002).

The high level of extrapair paternity generated substantial variation in reproductive success among males. Standardized variance in male reproductive success was $\sim 4 \times$ as high as that of females, indicating strong potential for sexual selection among males. Much of this potential for selection is attributable to EPFs: the extrapair component of variance accounted for about half of overall variance, and much of the within-pair variance was due to cuckoldry. It is apparent that the opportunity for sexual selection in our study population is much higher than it would be in the absence of EPFs.

Our finding that within-pair and extrapair success both made large contributions to overall variance in male reproductive success suggests that sexual selection may act on two sets of male traits. Selection may favor traits that enhance within-pair success (e.g. traits that help a male attract, defend, and control the behavior of a fecund social mate) and traits that increase a male's success at obtaining extrapair partners. The lack of covariance between within-pair and extrapair components of male success suggests that selection could act independently on those two sets of traits. Such independence might arise if the traits that enhance a male's ability to guard his social mate and deter rivals seeking to copulate with her differ from those that make him an attractive partner to females seeking EPFs, as suggested by our finding that more than half of the males that achieved EPFs were themselves cuckolded.

\section{Comparisons to Other Wood-Warbler Species}

Studies of extrapair paternity in other socially monogamous, sexually dimorphic paruline warbler species have yielded results similar to those for our population of Chestnut-sided Warblers, with some intriguing differences (Table 3). For example, Webster et al. (2001) assessed paternity in Black-throated Blue Warblers (D. caerulescens) and found that standardized variance in male reproductive success was very similar to the level we found for male Chestnut-sided Warblers (0.74 vs. 0.70 [our study]). Webster et

TABLE 3. Extrapair paternity in seven wood-warbler (Parulidae) populations.

\begin{tabular}{lccl}
\hline \hline & $\begin{array}{c}\text { Percentage of broods } \\
\text { with extrapair } \\
\text { offspring }\end{array}$ & $\begin{array}{c}\text { Percentage of } \\
\text { offspring that } \\
\text { are extrapair }\end{array}$ & Reference \\
\hline Chestnut-sided Warbler & 60.6 & 47.4 & Present study \\
Hooded Warbler & 35.3 & 26.7 & Stutchbury et al. 1997 \\
Common Yellowthroat & 49 & 22 & Thusius et al. 2001 \\
American Redstart & 59 & 40 & Perreault et al. 1997 \\
Yellow Warbler & 53.8 & 33.1 & Yezerinac and Weatherhead 1997 \\
Yellow Warbler ${ }^{\text {a }}$ & 25 & 13 & Yezerinac et al. 1999 \\
Black-throated Blue Warbler & 53.9 & 34.2 & Webster et al. 2001 \\
\hline
\end{tabular}

\footnotetext{
aFar northern population.
} 
al. (2001) also found that EPFs contributed to variance in male success, but that the component of variance attributable to EPFs accounted for $<10 \%$ of total variance (compared with $44 \%$ in our study). Thus, the contribution of EPFs to variation in male reproductive success appears to be lower in Webster et al.'s (2001) population of Black-throated Blue Warblers than in our population of Chestnut-sided Warblers.

Among other paruline species, Yellow Warblers (D. petechia) also exhibit variance in male reproductive success because of EPFs (Yezerinac and Weatherhead 1997). Similarly, the success of Hooded Warbler (Wilsonia citrina) males in achieving EPFs showed a sharply skewed distribution (Stutchbury et al. 1997), and Common Yellowthroat (Geothlypis trichas) males that obtained EPFs had higher overall reproductive success than those that failed to obtain EPFs (Thusius et al. 2001). In contrast, Perreault et al. (1997) detected no increased variance in male American Redstart (Setophaga ruticilla) reproductive success because of EPFs, perhaps because the small portion $(<10 \%)$ of extrapair young to which paternity could be assigned did not represent a sample large enough to detect the extrapair component of reproductive success.

\section{A Mating-system Scenario}

Our findings suggest that the Chestnutsided Warbler's mating system is driven by high-stakes competition among males for EPFs. Most of the males in our study population that achieved EPFs gained them during their social mate's fertile period. Thus, the potential benefit of EPFs is apparently sufficiently high that males pursued them even when such pursuit left them vulnerable to loss of paternity at the home nest. All males, however, did not suffer equally from taking the risk; only about half of the males that achieved EPFs were cuckolded. Moreover, EPFs were distributed nonrandomly among broods, with an excess of broods containing either no EPFs or many EPFs, which indicates that females vary in their likelihood of having eggs fertilized by extrapair males. We speculate that this variability reflects differences in female willingness to accept extrapair partners, perhaps because females with high-quality social mates are less likely to pursue EPFs. Females have ample opportunity to assess and compare local males, because males are present and singing steadily on territories for several weeks before any female lays eggs, and singing and territory defense continue through the breeding season. We anticipate further investigation to determine if female choice of extrapair partners does indeed play a key role in the Chestnut-sided Warbler's mating system.

\section{AcKnowledgments}

We thank E. Goodwin for assistance in the field, and two anonymous reviewers for helpful comments. B.E.B. was supported by a Faculty Research Grant from the University of Massachusetts and D.F.W. by the University of Kentucky and grants from the National Science Foundation. For more information on the SticiGui Probability Calculator, see www.stat.berkeley.edu/ stark/Java/ProbCalc.htm.

\section{Literature Cited}

Alatalo, R. V., K. Gottlander, and A. Lundberg. 1986. Extra-pair copulations and mate guarding in the polyterritorial Pied Flycatcher Ficedula hypoleuca. Behaviour 100:139-155.

Arak, A. 1984. Sneaky breeders. Pages 154-194 in Producers and Scroungers (C. J. Barnard, Ed.). Croom Helm, Beckenham, United Kingdom.

Arnold, S. J., ANd M. J. Wade. 1984. On the measurement of natural and sexual selection: Theory. Evolution 38:709-719.

Bassam, B. J., G. Caetano-Anollés, and P. M. Gresshoff. 1991. Fast and sensitive silver staining of DNA in polyacrylamide gels. Analytical Biochemistry 196:80-83.

Byers, B. E. 1995. Song types, repertoires, and song variability in a population of Chestnut-sided Warblers. Condor 97:390-401.

Dawson, R. J. G., H. L. Gibbs, K. A. Hobson, and S. M. Yezerinac. 1997. Isolation of microsatellite DNA markers from a passerine bird, Dendroica petechia (the Yellow Warbler), and their use in population studies. Heredity 79:506-514.

Gowaty, P. A., AND D. W. Mock, Eds. 1985. Avian monogamy. Ornithological Monographs, no. 37.

Griffith, S. C., I. P. F. Owens, and K. A. Thuman. 2002. Extra pair paternity in birds: A review of interspecific variation and adaptive function. Molecular Ecology 11:2195-2212.

Hancock, J. M. 1999. Microsatellites and other simple sequences: Genomic context and mutational mechanisms. Pages 1-9 in Microsatellites: Evolution and Applications (D. B. Goldstein and C. Schlötterer, Eds.). Oxford University Press, New York. 
LACK, D. 1968. Ecological Adaptations for Breeding in Birds. Methuen, London.

Marshall, T. C., J. Slate, L. KruUk, and J. M. Pemberton. 1998. Statistical confidence for likelihood-based paternity inference in natural populations. Molecular Ecology 7:639-655.

Møller, A. P., AND T. R. Birkhead. 1994. The evolution of plumage brightness in birds is related to extrapair paternity. Evolution 48:1089-1100.

Møller, A. P., And P. Ninni. 1998. Sperm competition and sexual selection: A meta-analysis of paternity studies of birds. Behavioral Ecology and Sociobiology 43:345-358.

Neuhauser, M., W. Forstmeier, and F. Bretz. 2001. The distribution of extra-pair young within and among broods-A technique to calculate deviations from randomness. Journal of Avian Biology 32:358-363.

Owens, I. P. F., And I. R. Hartley. 1998. Sexual dimorphism in birds: Why are there so many forms of dimorphism? Proceedings of the Royal Society of London, Series B 265:397-407.

Perreault, S., R. E. Lemon, and U. Kuhnlein. 1997. Patterns and correlates of extrapair paternity in American Redstarts (Setophaga ruticilla). Behavioral Ecology 8:612-621.

Petrie, M., and B. Kempenaers. 1998. Extra-pair paternity in birds: Explaining variation between species and populations. Trends in Ecology and Evolution 13:52-58.

Primmer, C. R., N. Saino, A. P. Møller, and H. ELLEGREN. 1998. Unraveling the process of microsatellite evolution through analysis of germ line mutations in Barn Swallows (Hirundo rustica). Molecular Biology and Evolution 15: 1047-1054.

Quinn, T. W., And B. N. White. 1987. Identification of restriction fragment-length polymorphisms in genomic DNA of the Lesser Snow Goose (Anser caerulescens caerulescens). Molecular Biology and Evolution 4:126-143.

Stutchbury, B. J. M., W. H. Piper, D. L. Neudorf, S. A. Tarof, J. M. Rhymer, G. Fuller, and R. C.
Fleischer. 1997. Correlates of extra-pair fertilization success in Hooded Warblers. Behavioral Ecology and Sociobiology 40:119-126.

Summers, K., And W. Amos. 1997. Behavioral, ecological, and molecular genetic analyses of reproductive strategies in the Amazonian dart-poison frog, Dendrobates ventrimaculatus. Behavioral Ecology 8:260-267.

Thusius, K. J., P. O. Dunn, K. A. Peterson, and L. A. Whittingham. 2001. Extrapair paternity is influenced by breeding synchrony and density in the Common Yellowthroat. Behavioral Ecology 12:633-639.

Webster, M. S., H. C. Chuang-Dobbs, and R. T. Holmes. 2001. Microsatellite identification of extrapair sires in a socially monogamous warbler. Behavioral Ecology 12:439-446.

Webster, M. S., S. Pruett-Jones, D. F. Westneat, AND S. J. Arnold. 1995. Measuring the effects of pairing success, extra-pair copulations and mate quality on the opportunity for sexual selection. Evolution 49:1147-1157.

Westneat, D. F., P. W. Sherman, and M. L. Morton. 1990. The ecology and evolution of extra-pair copulations in birds. Current Ornithology 7: 331-369.

Winker, K., T., C. Glenn, and G. R. Graves. 1999. Dinucleotide microsatellite loci in a migratory wood warbler (Parulidae: Limnothlypis swainsonii) and amplification among other songbirds. Molecular Ecology 8:1553-1556.

Yezerinac, S. M., H. L. Gibbs, J. V. Briskie, R. Whittam, And R. Montgomerie. 1999. Extrapair paternity in a far northern population of Yellow Warblers Dendroica petechia. Journal of Avian Biology 30:234-237.

Yezerinac, S. M., and P. J. Weatherhead. 1997. Extra-pair mating, male plumage coloration and sexual selection in Yellow Warblers (Dendroica petechia). Proceedings of the Royal Society of London, Series B 264:527-532.

Asssociate Editor: M. T. Murphy 